\title{
Intercomprendersi - a teacher training experience
}

\author{
Barbara Gramegna. Dipartimento Istuzione e Formazione Italiana Provincia di Bolzano (Italia)
}

Recepción: 23/07/2018 | Aceptado: 30/04/2019

Correspondencia a través de ORCID: Barbara Gramegna

iD $0000-0002-0237-2954$

Citar: Gramegna, B (2019). Intercomprendersi - a teacher training experience. ReiDoCrea Monográfico sobre Perspectivas transnacionales en la enseñanza de lenguas, 8(3), 225-237.

\begin{abstract}
This contribution presents a teacher-training program delivered by the Italian Educational Department in the Autonomous Province of Bolzano (Italy) centred on Intercomprehension theory. It was addressed to teachers in service with the aim of combining both purposes of plurilingual and intercultural education. Considered that linguistic competence is essential for developing knowledge in every school subject, the purpose of this training was to offer practical suggestions to become aware of how interlinguistic, receptive skills and decoding strategies can be applied in combination to facilitate comprehension tout court and to achieve mediation skills and language awareness. The paper offers some considerations about today's language teaching/learning processes in schools and about the changing role of teachers. The third section introduces the concept of Intercomprehension and its value for teacher training. The paper focuses on a description of the phases of the teacher training program conducted in 2017. It illustrates briefly the context, the needs assessment process, the aims and contents. The fourth section provides a summary and analysis of participants' feedback, with ideas for future developments and conclusive remarks.
\end{abstract}

Keywords: Teacher training Language instruction

\section{Intercomprendersi - Una experiencia de formación de docentes}

Resumen: Esta contribución presenta un programa de Intercomprensión docente impartido por el Departamento de Educación Italiano en la Provincia Autónoma de Bolzano (Italia) centrado en la teoría de la Intercomprensión. Se dirigía a los profesores en servicio con el fin de combinar los dos objetivos de la educación plurilingüe e intercultural. Considerando que la competencia lingüística es esencial para el desarrollo del conocimiento, el objetivo de esta formación era ofrecer sugerencias prácticas para mostrar cómo las habilidades interlingüísticas, receptivas y las estrategias de decodificación pueden ser aplicadas en combinación para facilitar la comprensión y para lograr las habilidades de mediación y la conciencia lingüística. El documento ofrece algunas consideraciones sobre los procesos de enseñanza/aprendizaje de idiomas en las escuelas y sobre el rol cambiante de los profesores. La tercera sección introduce el concepto de Intercomprensión y su valor para la formación del profesorado. El documento se centra en una descripción de las fases del programa llevado a cabo en el año 2017. Ilustra brevemente el contexto, el proceso de evaluación de las necesidades, los objetivos y los contenidos. La cuarta sección ofrece un resumen y un análisis de los comentarios de los participantes, con ideas para futuros desarrollos y las conclusiones.

Palabras clave: Formación del personal docente Enseñanza de idiomas

\section{Introduction}

The heterogeneity of the today classrooms requires new methodological approaches and new attitudes, not only about language teaching or teaching in general but also about living in a complex society. The complexity of contemporary society is more than ever built up not only by evident and incontrovertible social inequities but also by macro factors like language and cultural diversities. Therefore, the needs and requirements of quality education concerning: development of intercultural competencies, development of language competencies, development of democratic citizenship, diversity management, respecting otherness, protecting minority languages, reflecting on one's own sociolinguistic belonging moved, since the 1990s, European institutions, to prepare, discuss and let disseminate various kind of documents addressed to the single member States in order to encourage adequate education and language policies. 
From the European Charter for Regional or Minority Languages (1992) to the recent Guide for the Development and Implementation of curricula for Plurilingual and Intercultural Education (2016) is clear that Europe is pursuing a dual concept of education and inclusion: inclusion and appreciation of its historical already existing linguistic and cultural varieties and inclusion of the new repertories of all the pupils attending nowadays European schools. In several European countries, in fact, minority languages coexist with national languages and their use is ruled by local Language Policies, according to principles contained in after-war peace treaties and in following special laws. South Tyrol, the context of this teacher training experience, is one among them, it is a little Province in the Alps on the border of Italy and Austria, where recognizing the bi/trilingualism (German, Italian, Ladin) of its society and guaranteeing a bilingual education to every inhabitant, represents only a starting point for developing plurilingual and intercultural education. According to South Tyrol's Autonomy Statute (1972), every South Tyrolean citizen has in fact right to be taught in his own 'mother tongue' (L1) and in the second language (L2). Hence, there are schools with Italian language of schooling, where German is the L2, and schools with German language of schooling, where Italian is the L2, as well as schools with Ladin - Italian - and German as equally distributed languages of schooling, in two Ladin-speaking valleys of the Province. Although ranking languages in L1, L2 and so on is today, like I will then assert, something unrealistic. So, the given sociolinguistic and educational context influences and determines, in designing a suitable teacher training, the extent to which plurilingual and intercultural education can be intended.

The following description of a successful teacher training activity proposed a couple of years ago to teachers of school with Italian as language of schooling, in Bolzano, the capital town of South Tyrol, intends to be inspiring for language and intercultural education policy makers, for language teacher training managers, for school heads, for language teachers, for curriculum designers. Highlighting the role of language and intercultural education in improving mutual understanding and respect among the citizens of Europe was in fact one of the reasons of having chosen Intercomprehension as focus of the training proposal, another reason was that of giving response to teacher's training request towards innovative and cross-cutting approaches. The traditional concept associated with "foreign/language learning" is in today classrooms completely to be rethought.

Once was rather clear that a "foreign language" was for students an unfamiliar language spoken in a different country from that they lived in and teachers of "foreign" languages were the only native, or nativelike speakers, and testimonials of this language and related culture, but now the so-called foreign languages taught at school are often languages spoken at home by many students. How the various languages are considered inside the classroom is therefore not irrelevant and has many consequences, firstly the way each single school intends to design its curriculum in plurilingual and intercultural education. The concept of mother-tongue itself is a very gendered one and that foresees a kind of stereotyped value relating both to familiar and cultural identity. Increasing populations' movements and multilingual contexts lead to constant redefinitions. Mother-tongue is today often corresponding to a language spoken at home but is neither the language of the mother nor that of the father. Many parents choose for example to use the language of schooling, or of the host country, even at home, so that the number of plurilingual pupils is increasing.

According to what contained in the document Plurilingual Education in Europe (Council of Europe, 2006: 5): "A plurilingual person has: a repertoire of languages and language varieties; competence of different kinds and levels within repertoire. And a "plurilingual education promotes: an awareness of why and how one learns the languages one has chosen, an awareness of and the ability to use transferable skills in language learning, 
a respect for the plurilingualism of others and the value of languages and varieties irrespective of their perceived status in society, a respect for the cultures embodied in languages and the cultural identities of others, an ability to perceive and mediate the relationship which exist among languages and cultures, a global integrated approach to language education in the curriculum". Then the so-called language of schooling is not always the national language of the host country, like in South Tyrol, an Italian province, where possible languages of schooling are three (Italian, German and Ladin) and where two of them are not belonging to the same language family, or like in Catalunya in Spain, where Catalan, although a Romance language, is not automatically easy to be learned by people with Latin-American origins. So plurilingual learners require teachers who take their linguistic repertoire and diversity into account to avoid exclusion. If for all this the concept itself of "foreign languages" must be reviewed, then even more that of language education and language teaching, must be reconsidered, in their pedagogical, organizational and technical dimension. Assumed that language education is part of a wider educational program (curriculum) and that is not only based on mere language acquisition theories or only addressed to pursue high language performances, then its pedagogical dimension is really to be retrieved.

Reuven Feuerstein, Israeli psychopedagogist principally interested in finding techniques improving the learning potential of learners with special needs, recognized, already between 50 s and 60 s that the act of teaching is a mediation act. He identifies inside the so called MLE, Mediated Learning Experience, 9 mediation fields, where teachers, more than transfer knowledge, shall encourage pupils learn to learn. Feuerstein created so the prerequisites of autonomous and student-centered learning theories and he inspired several Union documents like that for example of 2006, The Recommendation on key competences for lifelong learning, where one of the 8 key competences is precisely that of "learn to learn". Transferring Feuerstein's considerations about teaching in general to language teaching in particular and identifying this teacher's mediation role in the language classroom, is clear that language learning abilities that like setting objectives, knowing how to use some skills, transferring and extending them, profiting of the knowledge of a minority or less prestigious language are abilities that must be strongly supported. Students may hold a repertoire of languages, styles, registers and genres, all at different levels of competence.

So, the main task of language teachers, and of a teacher in general, is to offer a technical-strategical mediation and to help his students in becoming aware of already possessed skills, useful in developing cross-cutting strategies and in transferring them from one language to another. Through this conscious mediation action teachers of all subjects could really make the difference in acquisition processes. Teacher training in an area of language and intercultural education is, for this reason, today more important than in the past; it is fundamental to point out how quality language teaching is in multilingual classrooms conditioned by factors that are not only linked with traditional language teaching activities. Compartmentalized and monolingual approaches, separation of language from subject teaching, resistance to profit of learners' plurilingual repertoires are realistically to be exceeded. Teachers of all subjects, and over all language teachers, need to collaborate in helping their pupils' developing metacognition, achieving higher awareness and self-regulation. (Pérez Valverde \& Ruiz-Cecilia, 2012). All this takes language education necessarily beyond the traditional confines of the "foreign language classroom" into the more faceted teaching and learning of the languages of schooling, of regional, minority and migrants' languages - until now largely unexplored education contexts - of intercomprehension between related languages. The requested multicompetences of learners should correspond, on the other side, to new and additional competences of teachers. Moreover, language skills have a relevant function in shaping the universe, each 
language and each subject, on its own, contribute together to prepare pupils for a global citizenship and only up to date teachers can meet this challenge. Therefore, to support teacher education and their professional growth is crucial for the achievement of educational policy goals (Cfr. Supporting teacher competence development for better learning outcomes, 2013). Assumed that the teacher itself has a mediator role, even more is acknowledged that mediation and comprehension are the most precious competences in a society characterized by "superdiversity", so as Vertovec (2007) define it, it is in fact avoiding and managing misunderstandings, allowing negotiations, enabling efficacious interaction, in few words: building bridges, that allows everybody to live in a complex society. These abilities should however not to be intended as practices or as processes but should become an aim in their selves. Reflecting upon the importance of mediation and comprehension abilities in the curriculum for language and intercultural education leads consequently to reflect upon the main components of mediation: reception, awareness and understanding. Reception could happen from a written, from an oral/auditive or from an iconic text; awareness is more a holistic approach, something that includes processing the stimulus. According to Carter language awareness is, "an enhanced consciousness of and sensitivity to the forms and functions of language" (Cfr. Carter, 2003: 64). Understanding is, according to the Programme for International Student Assessment (PISA), a literacy, or rather "the ability to extract the relevant information from texts and also to understand, use and reflect on texts". Texts are meant both written and oral. Extracting relevant information and understanding them, includes constructing meaning through interaction with the text, involvement with language, experience, knowledge.

In a multilingual classroom, where many individuals are plurilingual, reception, awareness and comprehension are already experienced in an intralinguistic and in a interlinguistic way. These learners are thus trained to employ intercomprehension techniques. Demonstrated that plurilingual people are today more than monolingual and that school classrooms are mostly composed by plurilingual pupils, the last edition of CEFR Companion Volume with New Descriptors (2018) added to the descriptors Mediation and Plurilingual and pluricultural competence; in the first one appears the ability of "facilitating pluricultural space" and in the second one appears "plurilingual comprehension". Both are points that could be related with Intercomprehension. According to a synthesis proposed by Bonvino and Jamet (2016) among the many existing definitions "the term Intercomprehension defines a communicative situation, where the parts, although expressing each in a different language, understand each other, both in writing and in speaking, both in presence and remotely, both synchronous and asynchronous. It defines also a teaching approach that intend to determine favorable conditions for this kind of communication".

The principle of Intercomprehension is based in language familiarities: working with the Romance language family is for example the proposal of the biggest project existing and called at the beginning EuRom4 (working with Italian, Spanish, Portuguese and French), now Eurom5 (Catalan was added). This method uses the close relation existing in five Romance languages: Italian, Spanish, Portuguese, Catalan and Roman. The aim is promoting reading comprehension, developing and letting cognitive language understanding processes become conscious. There are other methods and projects in Europe with Germanic and Slavonic languages as well, but EuRom5 offers a handbook with selected reading texts (in a difficulty progression order), that are methodologically tested and accompanied by short grammar notes, audio tracks, lexical boxes, methodological use suggestions. The linguistic output of Intercomprehension is not possible and therefore there is no measurable written or oral production, but there is anyway a production of meaning, a clarification of cognitive processes and of metalinguistic activities. According to Bonvino "the principles that typify Intercomprehension's approach to teaching may be summarized as follows: 
Plurilingual approach, Partial competences, Attention to comprehension, Learning transversality, Reflection on languages and role of L1". Intercomprehension is therefore also one of the theoretical frameworks the European Centre for Modern Languages $(E C M L)$ is referring to in describing how projects like FREPA (A Framework of Reference for Pluralistic Approaches to Languages and Cultures) contribute to plurilingual education.

In the Guide for the development and implementation of curricula for plurilingual and intercultural education (2016) the word Intercomprehension recurred many times and especially in the section dedicated to "experiences relating to the similarities and differences between languages". Intercomprehension is a suggested methodology also for supporting regional, heritage or and minority language learning and is a point in the agenda for teacher's additional required competence. So is rather clear that teachers shall be trained to work in their classrooms with Intercomprehension as well. Intercomprehension is, finally, not only to be reduced to a mere language understanding support but also to be seen as mediation and comprehension strategy.

Intercomprehension and its teaching implications are, under a linguistic point of view, study object since 1970s under the name of "didactique des langues voisines", as L. Dabène called it (1975), then in 1990s some European teams began to work on projects like for example that coordinated by C. B. Benveniste for the Eurom4 (today the above mentioned Eurom5). During the below illustrated teacher training experience the teacher trainer employed for some activities various texts from Eurom5.

\section{The inclusive dimension of Intercomprehension}

The term "inclusive education" appeared in The World Declaration on Education for All (1990) and from this moment forwards a principle guiding all education policies and practices, finding its roots in The Universal Declaration of Human Rights (1948) passing through The Convention on the Rights of the Child (1989) and through The Convention on the Protection and Promotion of Diversity in Cultural Expressions (2005) until $A$ Guide for ensuring inclusion and equity in education (2017). Inclusion means that all learners have equal right to learn and building inclusive education is an ongoing process, that requires standing efforts to facilitate and find inclusive practices within education systems; conditioning factors are, so as contained in Unesco's Guide for ensuring inclusion and equity in education (2017) "teacher skills and attitudes, infrastructure, pedagogical strategies and the curriculum".

The guide is intended "for use by key government education policy-makers, working with key stakeholders such as teachers and other educators, students, families, and community representatives. The guide could also assist development partners in facilitating a policy review process". Furthermore, one of the 4 Key Features identified in one of the 4 Dimensions of the Policy Review Framework of this guide, that of the Practice, is "Teachers and support staff have opportunities to take part in continuing professional development regarding inclusive and equitable practices".

Achieving more inclusive and cohesive societies and changes in the cultural function of the school is the reason why many Union instruments, like Erasmus+, the European Structural and Investment Funds, Creative Europe, Europe for Citizens, the Rights, Equality and Citizenship Programme, the European Solidarity Corps and Horizon 2020, were created. All these instruments tend to promote: exchange, sharing and dissemination of new theories, researches, good practices, mental attitudes. 
In April 2018, it was formulated by the European Council a proposal for a Recommendation "promoting common values, inclusive education, and the European dimension of teaching". One of the objectives of ET 2020 (The framework for European cooperation in education and training) is in fact to "promote equity, social cohesion and active citizenship, it has been established on the basis that education should promote intercultural competences, democratic values and respect for fundamental rights, prevent and combat all forms of discrimination and racism, and equip children, young people and adults to interact positively with their peers from diverse backgrounds".

Access to knowledge is subordinated to the social, cultural, linguistic perceptions specific to each learner, providing learners with tools that can enrich their world repertoire is so one goal of inclusive education. Providing teachers with methods and strategies that contribute to this enrichment is equally significant. Among the over mentioned Union initiatives, EVAL-IC, an Erasmus+ /Partnership project, gathers for example, researchers and teachers of 8 countries, Austria, Belgium, Germany, Spain, France, Italy, Portugal and Romania and from 14 institutions specialized in Intercomprehension, working for the development and evaluation of plurilingual and Intercomprehension competences.

One of the purposes of this project is to elaborate a protocol, fine descriptors and scales to be able to evaluate Intercomprehension competences in Romance languages.

\section{Objectives e hypotheses}

In the delivered teacher training the main aim was to develop educational skills that are compatible with both European and Italian education policies in the field of plurilingual and intercultural education and to enable teachers to comply the principles contained in these policies.

So, the European references in arranging this teacher education action were The Guide for the Development of Language Education Policies (2003); Les dimensions linguistiques de toutes les matiers scolaires. Un Guide pour l'elaboration des curriculums et pur la formation des enseignants (2015); The Guide for the development and implementation of curricula for plurilingual and intercultural education (2016) and the CEFR Companion Volume with new descriptors (2018).

The Italian references were in particular the Linee guida per l'accoglienza $e$ l'integrazione degli alunni stranieri (2014); Diversi da chi? Raccomandazioni per l'integrazione degli alunni stranieri e per l'intercultura (2014); the local references were the Indicazioni Provinciali per il Primo ciclo (2015).

All these documents contain explicit or indirect suggestions about the necessity of finding new approaches and new ways to increase awareness, consciousness and sensibility of teachers and students in relation to their own identity, both linguistic and cultural, to be able to recognize, but at the same time, to profit of diversity (linguistic and cultural), to promote cultural sensitivity, insight, and local knowledge and to develop skills and strategies of negotiations, mediation, metacognition transferable from one language/culture to another.

In the Province of Bolzano, where German, Italian and Ladin (a not very spread romance language spoken by $4,5 \%$ of the South Tyrolean population) are official languages. In many schools with Italian as language of schooling are Italian and German (compulsory L2 according to the local provincial education laws) taught almost 
for the same number of hours a week (from10 up to13); English is then considered the real first "foreign language". Many teachers come from other Italian provinces and possess few or no knowledges of German, but more knowledges of English or French. There are some bilingual teachers, whose home languages are Italian and German.

In Italian schools, the number of pupils with migration background is around $25 \%$; in many schools, there are more than $50 \%$ pupils with migration background speaking at home not less than two languages, so that they should learn at school at least other two. The composition of the classrooms determined in the last decade a change in teachers' needs. Every year the Educational Department in the Autonomous Province of Bolzano projects a rich Teacher Training Programme based on the guidelines suggested by the National Ministry of Education, on the Provincial School Policy priorities, on the need expressed by the single school of the province in its planning autonomy. Especially in the last 5 years the request of teacher training in the fields of language education and of social inclusion, accompanied by a constant need of innovative teaching methods, was increasing. Assessing teachers' needs is fundamental, it offers direction to enhance quality teaching. Assessing teachers' needs for in service training and arranging the provision of professional learning opportunities, so that teachers continue to develop their competences throughout their whole careers' is in fact one of the points of the introduction to the in 2.2 already mentioned European Commission document on teachers' professional development.

There is a shared agreement that, for teachers, the acquisition and development of competences needs is to be thought as a career-long endeavor and well-designed teachers' development support is strictly related to teachers' effectiveness and, at the end, to students' performances. For the already meantioned reasons, Intercomprehension was object of the training.

In designing the training was however not easy to select the contents for the disposable hours amount (18). Imagining these sessions addressed to people not acquainted with Intercomprehension, it was necessary to think about an introduction to Intercomprehension's theory and to its linguistic and intercultural dimensions, focus of the course, but also to integrate theory with a bit of "tasting" practical activity. So that, in agreement with the trainer, a mix approach (both theoretical and practical, with both individual and group activities) was preferred. It was then relevant both for trainer and training manager to show teachers how could an Intercomprehension activity work in their classroom. To the planned sessions was therefore added a session in the classroom with students.

General aims of the training, according to what pointed out at the beginning of the paragraph were:

- To present to teachers Intercomprehension as a possible approach in language teaching, also in the teaching of the language of schooling;

- To inform teachers of the advantages of using Intercomprehension activities in the classroom;

- To provide teachers with new methodological approach in language teaching;

- To provide them with new resources;

- To encourage a reflection about language acquisition strategies, about language learning processes, about by nature already present intercomprehension skills 
- To underline the role of cultural dimension in language learning and the consequent intercultural dimension of intercomprehension activities in classroom (promotion of mediation and negotiation).

\section{Method}

The contents, selected for 6 work sessions, 3 hours each, were therefore:

\section{An introduction to Intercomprehension}

- From a natural ability to a language teaching methodology: written and oral Intercomprehension, interactive platforms.

- Psycho-cognitive mechanisms: individual peculiarities of learners, language correspondences, language and relational strategies.

- Led written Intercomprehension activity (EuRom method).

2. (Meta)linguistic strategies and intercultural dimension of Intercomprehension

- Role of culture and affective dimension in Intercomprehension.

- Questionnaire's function as assessment and self-assessment mean.

- Intertextual Intercomprehension activity (Euronews).

3. Optional classroom activity with a volunteer teacher and her pupils

4. What does comprehension mean

- Related languages (Romance languages).

- What and why can I understand.

- Intercomprehension activity (EuRom method).

- 5. What characterizes an effective Intercomprehension

- Comparative reflections on various language immersion situations.

- Final considerations and questions.

- Intercomprehension activity between not related languages (EU\&I).

The third session was planned in agreement with the volunteer teacher of the group; she is History and Latin teacher in a scientific high school with Italian as language of schooling. The pupils of this school learn Latin, German and English as compulsory languages. Few pupils of the class in which the Intercomprehension activity was offered, have migration background, but many are bilingual Italian/German.

The trainer who conducts such activity shall possessed the ideal competences required for a mixed teachers' group (teachers of various subjects and of different school levels) and for the aims of the training itself. He/she shall present a well-structured program but is at the same time receptive in understanding and processing information from the group; he/she has a solid background of theoretical and practical knowledge about the key aspects of language teaching, linguistic, intercultural, methodological. He/she shall propose mix activities with appropriate timing and selection of resources, from books and from the web (for example EuRom, Euromania, Miriadi, Redinter). He/she shall design and animate group tasks and run the following discussion in a non-directive manner, listening carefully to trainees, providing opportunities for participants to gain insights into their teaching habits. He/she shall have experience in Intercomprehension activities on his/her own. 
As ice-breaking activity in the first training session was proposed, for example, a questionnaire in Spanish, Cuestionario pre-lectura 1/Intercomprensión de lenguas romances, as initial challanging self-assessment, which intended to investigate their attitudes as readers.

The questionnaire included as well closed, open ended and mixed questions, like:

1. ¿Qué haces normalmente ANTES de leer?

2. ¿Qué haces normalmente MIENTRAS lees?

3. ¿Cómo te sientes cuando no comprendes 'suficientemente'?

4. ¿Cuánto te importa, en general, 'comprenderlo todo'?

5. ¿Qué haces cuando quieres 'comprender' más?

At the beginning the teachers felt a little bit disoriented, then in couples tried to exchange comments and discussed about their reading and understanding styles and expectations about a text in another language (Spanish was for nobody in the group neither a home nor a well-known language) and all that was relevant for the trainer to achieve the following objectives:

- to survey character of the group;

- to put teachers in pupils' shoes, when they are asked to read and understand something in a not known language;

- to become aware of their personal reading style.

Then a grid was submitted to explore their metacognitive/metalinguistic ability. They were in fact solicited to recognize: objective, strategies, other involved dimensions (relational/observational/interpretative/...) of each answer given before.

For example, for the first question:

1. ¿Qué haces normalmente ANTES de leer?

And among multiple choice possible answers:

A. Observo la estructura del texto (título, subtítulos, número de párrafos, eventuales imágenes) y hago hipótesis acerca de su contenido.

B. Trato de acordarme eventuales textos similares que ya pueda haber leído.

C. Pienso en mi experiencia y/o conocimientos acerca del tema.

D. Me pregunto cómo voy a leer y con cuáles objetivos.

The answer given was:

A. Observo la estructura del texto (título, subtítulos, número de párrafos, eventuales imágenes) y hago hipótesis acerca de su contenido.

Then teacher could have filled the grid like that:

Objectives

Strategies

Relational/observational... dimension 
1 A Global understanding

- Taking advantage of a familiar text structure;

- Using nonverbal comprehension strategies (pictures)

- Observational

- Interpretative

- Meaning searching

The effect of this activity was that it launched a discussion on reading and reading comprehension attitudes (one of the aims of the course) and a debate on understanding strategies in the own and other languages and on the role of other known languages in this comprehension process (other aims of the course).

At the end of the training both teachers and students were asked to give their opinion, teachers through a questionnaire and students through free delivered comments and a free participation at the last teacher training session.

The teachers declared many positive results of the training, like:

- Encouraging intercultural reflections (through comparative phrase analyzing exercises);

- Highlighting the interconnections between affective and cognitive processes;

- Enhancing the contribution of intercultural education practices;

- Letting emerge interlinguistic and transfer abilities.

Some of pupils' (17-18) statements about the Intercomprehension activity in the classroom were:

- "I was really impressed how I could understand languages that I never learned before thanks to the method we used; I became aware of something that usually maybe happens automatically".

- "It was an interesting experience, I couldn't imagine that something like that, I mean 'comprehend', is something that can be taught".

- "Wow, I could read and understand fully foreign languages. I wondered how I could do it".

- "I suggest extending this experience to all classes; I reflected about something that probably used to do unconsciously".

The comments covered different aspects of the classroom work but expressions of feeling like: surprise, satisfaction, self-efficacy, language awareness returned many times. Processing the feedback given by the two parts (teachers and pupils) of the experience, led to:

\section{Results}

- Intercomprehension showed even in short times its high potential;

- Individual plurilingualism of both teachers and pupils can through Intercomprehension positively emerge;

- Multilingualism of the classroom came to the surface;

- Intercomprehension task are ideal to develop cooperation and to further negotiation; the comprehension of a whole text results from a collective process; 
- The absence of a final translation like product (Intercomprehension is not a translation-process!) encourage every pupil to make proposals and remain active until the end of the proposed activity

- Reflections on language teaching:

- Practicing Intercomprehension gave teachers a concrete input to design new classroom activities;

- They realized how often neglected languages can be helpful for comprehension tasks;

- Traditional language teaching dedicates metalinguistic strategies too little time;

- Reflections on language learning:/intercultural education:

- Searching and deepening meaning of single words produces necessary discussion about cultural aspects of languages;

- Every existing competence languages could be used as basis for the understanding of other languages;

- Intercomprehension leads towards learner autonomy;

- Every existing intercultural competence could be used as basis for mediation;

- Metacognition is usually not practiced in everyday classroom activity;

- Latin learners are advantaged in Intercomprehension with EuRom5.

Extension of the sessions in the classroom: students asked for further sessions and declared that a shorter session once a week would be useful. Second part of the training: many teachers asked for a second part of the training with more Intercomprehension activities. Training sessions for primary school teachers and experience in the classroom: primary school teachers of the group asked for a special training. During the sessions, also Euromania materials were being used and they found them very interesting to work with in their classroom.

CLIL and Intercomprehension: language teachers proposed to deepen aspects emerged during the Intercomprehension exercise, that could be useful in language and content integrated learning.

Intercomprehension and subject teaching: teachers observed that after having experimented the first training session they were more able to distinguish difficulties, so as the strategies to overcome them, contained in texts they usually propose in the classroom as history or science teacher.

Applying Intercomprehension techniques in the South Tyrol language education working with Ladin/italian and German/English as couples of related languages.

Obviously, all these possible expansions are to be taken into account for future teacher training but the most relevant conclusion to draw is that teachers identified various fields of actions, where Intercomprehension could play a role and that students didn't exclude wider and longer Intercomprehension sessions as useful supports in different fields of application.

\section{Discussion}

In the introduction of this paper I intended to present a, for me as teacher training manager, successful teacher training experience. I started with analysing the changed conception of language and "foreign language" learning at school, with a focus on the necessity of reconsidering language teacher's role and the consequent importance of 
teachers' education. I introduced then the idea of why Intercomprehension was for me a good content for a training proposal and explained briefly what is meant with Intercomprehension in language learning and teaching. I tried therefore to illustrate the reasons that moved me to design this training and to share the various steps that accompanied the planning of the proposal, starting from the context, from the documents that guided me, without forgetting the training needs of teachers in my province.

In the second part of the description I reported about aims, contents and examples of the work with teachers and about the characteristic of the trainer. The last section was concerned with feedbacks of the participants and with reflections resulted of processing these feedbacks. Without claiming to be exhaustive I hope that the presented experience could be inspiring for teachers, teacher trainers, teacher training managers, school administrators and researchers.

Finally, what I really care about is the role of teachers' education inside school systems, because only teachers' effectiveness allows pupils to acquire today essential competencies, both language and intercultural "to communicate effectively in crosscultural situations and to relate appropriately in a variety of cultural contexts". (Bennett \& Bennett, 2004: 149). Innovative teacher education programmes and attention to the pedagogic dimension of language teaching are suitable areas for sharing opinions, good practices, researches.

\section{References}

Beacco, J.-C. (2005). Languages and language repertoires: plurilingualism as a way of life in Europe. Retrieved from https://rm.coe.int/CoERMPublicCommonSearchServices/DisplayDCTMContent?d ocumentld $=09000016802 \mathrm{fc} 1 \mathrm{c} 4$

Bennett, J. M. \& Bennett, M. J. (2004). Developing intercultural sensitivity: An integrative approach to global and domestic diversity, D. Landis, J. Bennett \& M. Bennett (Eds.), Handbook of intercultural training 3rd ed.,147-165. http://dx.doi.org/10.4135/9781452231129.n6

Bonvino E., Jamet M.C. (Eds.). (2016). Storia, strategie e sfide di una disciplina in espansione. Intercomprensione: lingue, processi e percorsi Intercomprensione: lingue, processi e percorsi. doi:10.14277/978-88-6969-134-8

Carter, R. (2003). Language Awareness. ELT Journal Volume 57/1, 64-65, Oxford University Press, Oxford. doi: 10.1093/elt/57.1.64

Council of Europe. (1992). Charter for Regional or Minority Languages, Strasbourg. Retrieved from https://rm.coe.int/168007bf4b

Council of Europe. (2006). Plurilingual education in Europe. Retrieved from https://www.ecml.at/Portals/1/documents/CoEdocuments/plurinlingaleducation_en.pdf?ver=2017-02-07-160535-763

Council of Europe. (2006). Recommendation of the European Parliament and of the Council on key competences for lifelong learning. Official Journal of the European Union. Retrieved from https://eurlex.europa.eu/LexUriServ/LexUriServ.do?uri=OJ:L:2006:394:0010:0018:EN:PDF

Council of Europe. (2010). Language and school subjects. Linguistic dimensions of knowledge building in school curricula, Retrieved from https://www.ecml.at/coedocs/language-dimensions-subjects-EN.pdf

Council of Europe. (2010). Language(s) of Schooling: Focusing on vulnerable learners, Retrieved from https://rm.coe.int/16805a1caf

Council of Europe. (2016). Guide for the development and implementation of curricula for 
Council of Europe. (2018). CEFR Companion Volume with new Descriptors,

Strasbourg. Retrieved from https://rm.coe.int/cefr-companion-volume-with-newdescriptors-2018/1680787989

EuRom5 http://www.eurom5.com/p/chisiamo/intercomprensione Retrieved April, 2, 2019

European Commission. (2006-2011). Supporting teacher competence development for better learning outcomes. Retrieved from

http://ec.europa.eu/dgs/education_culture/repository/education/policy/school/doc/ teachercomp en.pdf

European Commission. (2009). Strategic Framework - Education and training 2020. Official Journal of the European Union. Retrieved from https://ec.europa.eu/education/policies/european-policy-cooperation/et2020framework_en

FREPA a framework of reference for pluralistic approaches. Retrieved from https://carap.ecml.at/Teachertraining/Languagepoliciesmodule/tabid/2964/langua ge/en-GB/Default.aspx

MIUR. (2014). Linee Guida per l'accoglienza e l'integrazione degli alunni stranieri.

Roma, Italia: Ministero Istruzione Università Ricerca. Retrieved from http://www.istruzione.it/archivio/web/ministero/focus190214.html

MIUR. Osservatorio nazionale per l'integrazione degli studenti stranieri e l'intercultura. (2014). Diversi da chi? Raccomandazioni per l'integrazione degli alunni stranieri e per l'intercultura. Roma, Italia: Retrieved from www.istruzione.it/allegati/2015/cs090915_all2.docx

Pérez Valverde, C. \& Ruiz-Cecilia, R. (2012). Paving the way towards the ECTS system: Self-assessment, metacognition, and professional competence in a literature course for FL teachers. Porta Linguarum. Revista Internacional de Didáctica de las Lenguas Extranjeras, 17, 67-77.

Plurilingual and intercultural education. Strasbourg: Council of Europe Publishing.

Provincia Autonoma di Bolzano. Indicazioni Provinciali Indicazioni provinciali per la definizione dei curricoli del primo ciclo d'istruzione della scuola in lingua italiana della Provincia Autonoma di Bolzano. (2015). Bolzano, Italia. Retrieved from http://www.provincia.bz.it/formazione-lingue/scuolaitaliana/downloads/407114_Indicazioni_provinciali_I_ciclo.pdf

Südtiroler Landesregierung. (2005). Das neue Autonomiestatut. Bozen, Italien. Retrieved from http://www.provincia.bz.it/news/de/publikationen.asp

UN General Assembly Resolution. (1948). Universal Declaration of Human Rights. Retrieved from http://www.un.org/en/universal-declaration-human-rights/

UN General Assembly Resolution. (1989). Convention on the Rights of the Child. Retrieved from http://www.un.org/documents/ga/res/44/a44r025.htm

Unesco. (1990). The World Declaration on Education for All. Retrieved from https://unesdoc.unesco.org/ark:/48223/pf0000127583

Unesco. (2005). Convention on the Protection and Promotion of Diversity in Cultural Expressions, Unesco. Retrieved from http://portal.unesco.org/en/ev.phpURL_ID=12024\&URL_DO=DO_TOPIC\&URL_SECTION=201.html

Unesco. (2013). Intercultural Competences. Conceptual and operational framework. Unesco. Retrieved http://unesdoc.unesco.org/images/0021/002197/219768e.pdf

Unesco. (2017). A Guide for ensuring inclusion and equity in education. Unesco. Retrieved from http://unesdoc.unesco.org/images/0024/002482/248254e.pdf

Vertovec, S. (2007). Super-diversity and its implications. Ethnical and racial studies, 30, 1024-1054. doi: 10.1080/01419870701599465 